\title{
Expression Compilation of Several Putative Cancer Stem Cell Markers by Primary Ovarian Carcinoma
}

\author{
Jiabo Di ${ }^{1}$, Refika Yigit ${ }^{2}$, Carl G. Figdor ${ }^{1}$, Tjitske Duiveman-de Boer ${ }^{1}$, Leon F. A. G. Massuger ${ }^{2}$, \\ Ruurd Torensma ${ }^{1}$
}

${ }^{1}$ Departments of Tumor Immunology, Nijmegen Centre for Molecular Life Sciences, Radboud University Nijmegen Medical Centre,
Nijmegen, the Netherlands; ${ }^{2}$ Department of Obstetrics and Gynecology, Nijmegen Centre for Molecular Life Sciences, Radboud
University Nijmegen Medical Centre, Nijmegen, the Netherlands.
E-mail: r.torensma@ncmls.ru.nl.

Received July $23^{\text {rd }}, 2010$; revised July $26^{\text {th }}, 2010$; accepted August $3^{\text {rd }}, 2010$.

\begin{abstract}
Cancer stem cells (CSCs) or tumor initiating cells are rare cells that are able to establish a tumor or metastasis. Identification of those CSCs is, however, cumbersome even in established cell lines. Several cancer stem cell markers were reported to be expressed by ovarian cancer. Those cancer stem cells are gifted with lower vulnerability to irradiation and cytostatic drugs explaining the high incidence of recurrence after treatment. A variety of different cancer stem cell markers were described for epithelial tumors. Also, cancer cell lines were assessed for stem cell markers with no common denominator. The expression of CD24, CD44, CD117, CD133, ABCG2, ALDH was determined for cells from 22 patients. Ovarian cancer cells were collected from ascites. Part of the tumor cells were analyzed immediately and stained for the above mentioned cancer stem cell markers. The remainder of the cells was cultured for several weeks using standard stem cell culture conditions. We observed a large variety in expression of putative stem cell markers for primary tumors. After two weeks of culture spheres were seen in several cultures, indicative for cancer stem cells, though not all patients' cells were able to form spheres. Our data show for the first time the heterogeneity in marker display in primary tumors. Also for the cultured cells stem cell markers were determined. None of the stem cell markers was expressed by all patients' cells. No correlation with tumor type was demonstrated. The complexity of expression challenges the isolation of cancer stem cells.
\end{abstract}

Keywords: Ovarian Cancer, Cancer Stem Cells, Stem cell markers

\section{Introduction}

Ovarian cancer is the fifth leading cause of death from cancer in women and the most lethal gynecological malignancy. It has a poor prognosis due to late patient presentation because early symptoms are not evident or vague and confused with more common gastrointestinal diseases. The incidence of ovarian cancer is approximately 1 in 60 women. When diagnosed early the survival is far better than at advanced stages of the disease, at which point the 5-year survival is only $30 \%$. Moreover, the development of a chemoresistant tumor after surgery and chemotherapy aggravates the situation. Novel treatment modalities are needed to increase the survival rate.

Targeting the cancer stem cell (CSC) has been put forward as such a new treatment modality $[1,2]$. However, the CSC concept is heavily debated. The CSC is a

This study was supported by a grant from the Netherlands Institute for Regenerative Medicine. relatively rare cancer cell that has the ability to self-renewal giving rise to another malignant stem cell as well as commit to terminal differentiation into multiple lineages of more mature cancer cells [3-6]. The differentiated cells constitute the bulk of the tumor, but they lack self-renewal capacity and have limited proliferation potential.

Increasing experimental evidences suggest that CSCs may play a decisive role in the initiation and progression of tumors [7]. CSCs were originally identified in leukemia, Bonnet and co-workers demonstrated that human leukemias are driven by a small population of leukemic stem cells capable of transferring the disease to NOD/SCID mice [8]. This concept was extended to solid epithelial tumors by Al-Hajj and co-workers, who demonstrated that a small population of cells within breast cancer with stem cell properties, bearing the surface marker $\mathrm{CD} 24^{\text {low }} \mathrm{CD} 44^{\text {high }}$. Subsequently, CSCs are identified and prospectively iso- 
lated from a variety of epithelial cancers, including pancreas, colon and prostate cancers [5,9-15]. The cancer stem cell hypothesis has recently also been explored in ovarian cancer. In 2008, Zhang and co-colleagues claimed that epithelial ovarian cancers derive from a subpopulation of $\mathrm{CD}_{4} 4^{+} \mathrm{CD} 117^{+}$cells [16]. Recently, Ferrandina and Curley independently found that CD133 expression defines a tumor initiating subpopulation of cells in human ovarian cancer $[17,18]$. Moreover, Gao and co-workers reported that $\mathrm{CD} 24$ could be utilized as a surface marker to enrich ovarian CSCs [19]. Ovarian CSCs were also detected in the so-called side populations, which are tumorigenic and chemoresistant [20-22]. The hypothesis that CSCs are responsible for tumor recurrence and metastasis of ovarian cancer gets more and more support. If indeed CSCs are the targets to treat ovarian cancer, novel strategies have to be developed to target specifically those cells. Current chemotherapeutic drugs do not kill CSCs because those stem cells express several pumps, for instance ABCG2, that expel cytostatic drugs out of the cell $[22,23]$.

In the current study, we tested the expression of the described putative epithelial CSC markers in primary ovarian tumor ascites, in order to assess whether they can be utilized as general markers to identify and isolate ovarian CSCs. Our data shows that the expression of those CSC markers is very diverse and is patient-dependent, and no correlation was found between pattern of surface marker display and tumor histologicalsubtype. These suggest that ovarian tumors are heterogeneous, and a more general marker is needed to prospectively isolate or target ovarian CSCs for elimination.

\section{Materials and Methods}

\subsection{Primary Tumor Sphere Culture}

Freshly-isolated ascites fluid was received from the Department of Obstetrics and Gynecology, Radboud University Nijmegen Medical Centre. Following filtration through a $100 \mu \mathrm{m}$ cell strainer (BD Falcon ${ }^{\mathrm{TM}}$ ), viable ascites-derived mononuclear cells were isolated by centrifugation over Lymphoprep ${ }^{\mathrm{TM}}$ (Axis-Shield). The ascites-derived mononuclear cells were suspended in GIBCO $^{\text {TM }}$ Defined Keratinocyte-SFM (1x; Invitrogen) supplemented with recombinant human EGF $(20 \mathrm{ng} / \mathrm{ml}$; R\&D systems) and plated at a density of $2 \times 10^{6}$ tumor cells/24 well plate with Ultra-Low Attachment surface (Corning Incorporated). Cells were grown at $37^{\circ} \mathrm{C}$ with $5 \% \mathrm{CO}_{2}$ [24].

\subsection{Aldefluor Assay}

ALDEFLUOR assay was performed with the ALDEFLUOR kit from Stem Cell Technologies. Prior to treatment, cells were suspended in aldefluor assay buffer $(1 \times$
$10^{6} \mathrm{cell} / \mathrm{s} / \mathrm{ml}$ ). aldefluor assay reagent containing the ALDH substrate BODIPY-aminoacetaldehyde (BAAA) was added to both control and test samples $\left(5 \mu \mathrm{l} / 1 \times 10^{6}\right.$ cells $)$. Before addition of BAAA, the negative control sample was treated with a specific inhibitor of ALDH, diethylaminobenzaldehyde (DEAB, $5 \mu \mathrm{l} / 5 \times 10^{5}$ cells). Then the samples were incubated for 45 minutes at $37^{\circ} \mathrm{C}$ to allow conversion of the substrate BAAA to the fluorescent product BODIPY-aminoacetate (BAA). The amount of intracellular fluorescent product was then measured using a $\mathrm{CyAn}^{\mathrm{TM}}$ ADP flow cytometer (Beckman Coulter).

\subsection{Immunofluorescence Staining and Microscopy}

ALDEFLUOR treated cells were rinsed in PBS, and then cells were adhered to poly-L-lysine-coated cover slips and fixated with $2 \%$ PFA in PBS for 15 minutes. Cover slips were mounted onto glass slides with Mowiol. Subsequently, cells were examined by fluorescence microscopy (Olympus).

\subsection{Flow Cytometric Analysis of Cancer Stem Cell Markers}

Cells were isolated from ascitic fluid and cultured for two weeks in stem cell medium. To stain for cell surface markers, washed with PBA (PBS $/ 0.1 \%$ BSA $/ 0.1 \%$ sodium azide) and incubated with the following antibodies at $4^{\circ} \mathrm{C}$ for 30 minutes: CD24-PE (Beckman Coulter), CD44-APC (BD Pharmingen ${ }^{\mathrm{TM}}$ ), c-Kit-FITC (CD117) (Santa Cruz Biotechnology), CD133-PE (Miltenyi Biotec), ABCG2-PE (R\&D Systems). Before flow cytometric analysis the cells were washed and resuspended in PBA solution. Cells were then examined using the $\mathrm{CyAn}^{\mathrm{TM}} \mathrm{ADP}$ flow cytometer. The exitation wavelenght for FITC was $488 \mathrm{~nm}$ and emission wavelenght $530 \mathrm{~nm}$, for phycoerythrin excitation at $561 \mathrm{~nm}$ and emission at $585 \mathrm{~nm}$ and for allophycocyanin excitation at $643 \mathrm{~nm}$ and emission at $665 \mathrm{~nm}$.

\section{Results}

\subsection{Self-renewing Spheres Are Not Formed in All Patients with Ovarian Cancer}

One key determinant of stem cells is the capability for extensive proliferation. To demonstrate whether cells with distinct proliferation abilities were present in human ovarian tumors, we established cultures with ascites-derived tumor cells from 22 ovarian cancer patients. (Table 1). To assess the formation of tumor spheres, freshly isolated as well as frozen tumor cells were cultured under conditions proved to favor the growth of stem cells [16,25-27]. By this approach, we found that not all of the ascites yielded tumor spheres during pri- 
Table 1. Summary of patient population.

\begin{tabular}{|c|c|c|c|c|}
\hline $\begin{array}{l}\text { Ptn } \\
\text { No. }\end{array}$ & Age & $\begin{array}{l}\text { FIGO } \\
\text { stage }\end{array}$ & Histological subtype & $\begin{array}{c}\text { Sphere } \\
\text { formation }\end{array}$ \\
\hline 4 & 61 & III & Serous & Yes \\
\hline 10 & 85 & III & Adenocarcinoma* & Yes \\
\hline 14 & 81 & III & Adenocarcinoma* & No \\
\hline 15 & 62 & Ic & Endometrioid & Yes \\
\hline 17 & 57 & III & Serous & No \\
\hline 19 & 33 & III & Mucinous & No \\
\hline 20 & 73 & III & Serous & Yes \\
\hline 21 & 64 & III & Serous & No \\
\hline 23 & 57 & IV & Serous & No \\
\hline 30 & 46 & III & Adenocarcinoma* & Yes \\
\hline 31 & 67 & IV & Serous & No \\
\hline 33 & 84 & III & Serous & Yes \\
\hline 35 & 95 & III & Sarcoma & No \\
\hline 36 & 77 & IV & Serous & No \\
\hline 37 & 69 & III & Serous & No \\
\hline 41 & 36 & III & Mucinous & No \\
\hline 44 & 69 & III & Serous & No \\
\hline 45 & 77 & III & Serous & Yes \\
\hline 50 & 58 & III & Adenocarcinoma* & No \\
\hline 51 & 52 & Ic & Mucinous & Yes \\
\hline 52 & 63 & III & Adenocarcinoma* & No \\
\hline 55 & 63 & III & Serous & Yes \\
\hline
\end{tabular}

*: Histological subtype undefined; Ptn No.: patient number

mary culture for 2 weeks. Regardless of histological subtypes, only the cells from 9 out of the 22 patients were capable of generating sphere-like clusters (Table 2).

\subsection{Expression of Putative Ovarian CSC Markers Are Diverse Among Patients}

Ovarian CSCs were identified and prospectively isolated by several cell surface markers, including $\mathrm{CD} 44^{+} \mathrm{CD} 117^{+}$, $\mathrm{CD}_{133^{+}}$and $\mathrm{CD}^{+} 4^{+}[16,27]$. To investigate whether these markers are generally functional to isolate CSCs from all ovarian cancer patients, we cultured the ascites-derived tumor cells for 2 weeks and analyzed CSC marker expression by flow cytometry (Figure 1). Remarkably, we found that the expression pattern of these CSC markers was different among patients, and the expression of those markers was not associated with histological subtype of the patients. Moreover, we found no correlation between expressions of any of these CSC markers with the ability of tumor sphere formation.

We found cells from only 2 out of 11 patients expressed CD133, of which one patient had $73.3 \%$ while the other had only $3.7 \% \mathrm{CD} 133^{+}$cells. Both tumors were classified as serous adenocarcinoma. We also found that cells from all the 13 analyzed patients expressed CD24, although the CD24+ cells ranged from $3.2 \%$ to $86.7 \%$. Similarly, CD44 was also widely expressed, ranging from $2.2 \%$ to $88.2 \%$.
Table 2. Statistics of patient population $(n=22)$.

\begin{tabular}{ccc}
\hline Age & $33-95$ & 64 (median) \\
\hline & Ic & 2 \\
FIGO stage & III & 17 \\
& IV & 3 \\
& Serous & 12 \\
Histologic & Mucinous & 3 \\
subtype & Endometrioid & 1 \\
& Adenocarcinoma* & 5 \\
& Sarcoma & 1 \\
\hline
\end{tabular}

Included Ptn No.: 4, 10, 14, 15, 17, 19, 20, 21, 23, 30, 31, 33, 35, 36, 37, 41, $44,45,50,51,52,55$; *: Histological subtype undefined

Cells from only 1 in 13 patients had no CD44 expression and 2 out of 13 patients had very low CD44 expression. Interestingly, 2 of the 3 patients were diagnosed with mucinous adenocarcinoma while the other patient was difficult to be classified into histological subtype. In contrast to $\mathrm{CD} 24$ and $\mathrm{CD} 44$, the rare population of $\mathrm{CD} 117^{+}$cells was detected in 7 out of 11 patients, ranging from $2.9 \%$ to $11.2 \%$. We detected a low percentage $(<2 \%)$ of $\mathrm{CD} 44^{+} \mathrm{CD} 117^{+}$cells in 3 out of 6 patient ascites fluids. In addition to the $\mathrm{CD} 44^{+} \mathrm{CD} 117^{+}$cell population, we also observed patients with $\mathrm{CD} 44^{+} \mathrm{CD} 117^{-}$cells as well as patients with $\mathrm{CD} 44^{-} \mathrm{CD} 117^{+}$cell populations in the same histological subtype. Moreover, ABCG2 has been found over-expressed in $\mathrm{CD}_{133^{+}}$sphere-forming cells in ovarian cancer patients [16], and is believed to be associated with chemo-resistance. We therefore examined whether it is up-regulated in all ovarian cancer patients. We stained ascites-derived tumor cells after primary culture and test with the expression of surface markers, ABCG2 was also not detected in all the patients. We only observed a slight increase of ABCG2 expression $(<1 \%)$ in 1 out of the 13 patients.

Table 3. Overview of ALDH expression.

\begin{tabular}{|c|c|c|c|c|}
\hline \multirow{4}{*}{$\begin{array}{l}\text { Ptn } \\
\text { No. }\end{array}$} & \multicolumn{4}{|c|}{ Percentage of gated $\mathrm{ALDH}^{+}$cells in Region 2} \\
\hline & \multicolumn{2}{|c|}{ Before culture } & \multicolumn{2}{|c|}{ After primary culture } \\
\hline & With & Without & With & Without \\
\hline & DEAB & DEAB & DEAB & DEAB \\
\hline 4 & 0.02 & 1.18 & 0.03 & 0.44 \\
\hline 9 & 0.02 & 0.65 & 0.02 & 0.17 \\
\hline 10 & 0.02 & 6.99 & 0.02 & 0.18 \\
\hline 17 & 0.01 & 1.32 & - & - \\
\hline 19 & - & - & 0.01 & 2.54 \\
\hline 20 & 0.02 & 0.38 & 0.02 & 0.05 \\
\hline 21 & - & - & 0.02 & 0.54 \\
\hline 23 & 0.03 & 3.93 & 0.03 & 0.85 \\
\hline 30 & 0.01 & 2.74 & 0.01 & 0.01 \\
\hline 33 & - & - & 0.02 & 1.07 \\
\hline 35 & 0.01 & 1.65 & - & - \\
\hline 36 & 0.03 & 3.00 & 0.03 & 0.08 \\
\hline 42 & - & - & 0.03 & 0.05 \\
\hline 45 & 0.01 & 1.39 & 0.01 & 0.76 \\
\hline 50 & 0.03 & 0.18 & 0.03 & 1.29 \\
\hline 51 & 0.01 & 4.86 & 0.01 & 0.01 \\
\hline 52 & 0.02 & 0.72 & 0.02 & 0.08 \\
\hline
\end{tabular}

-: Data not available;Data displayed in percentage of positive cells; Ptn No.: patient number 

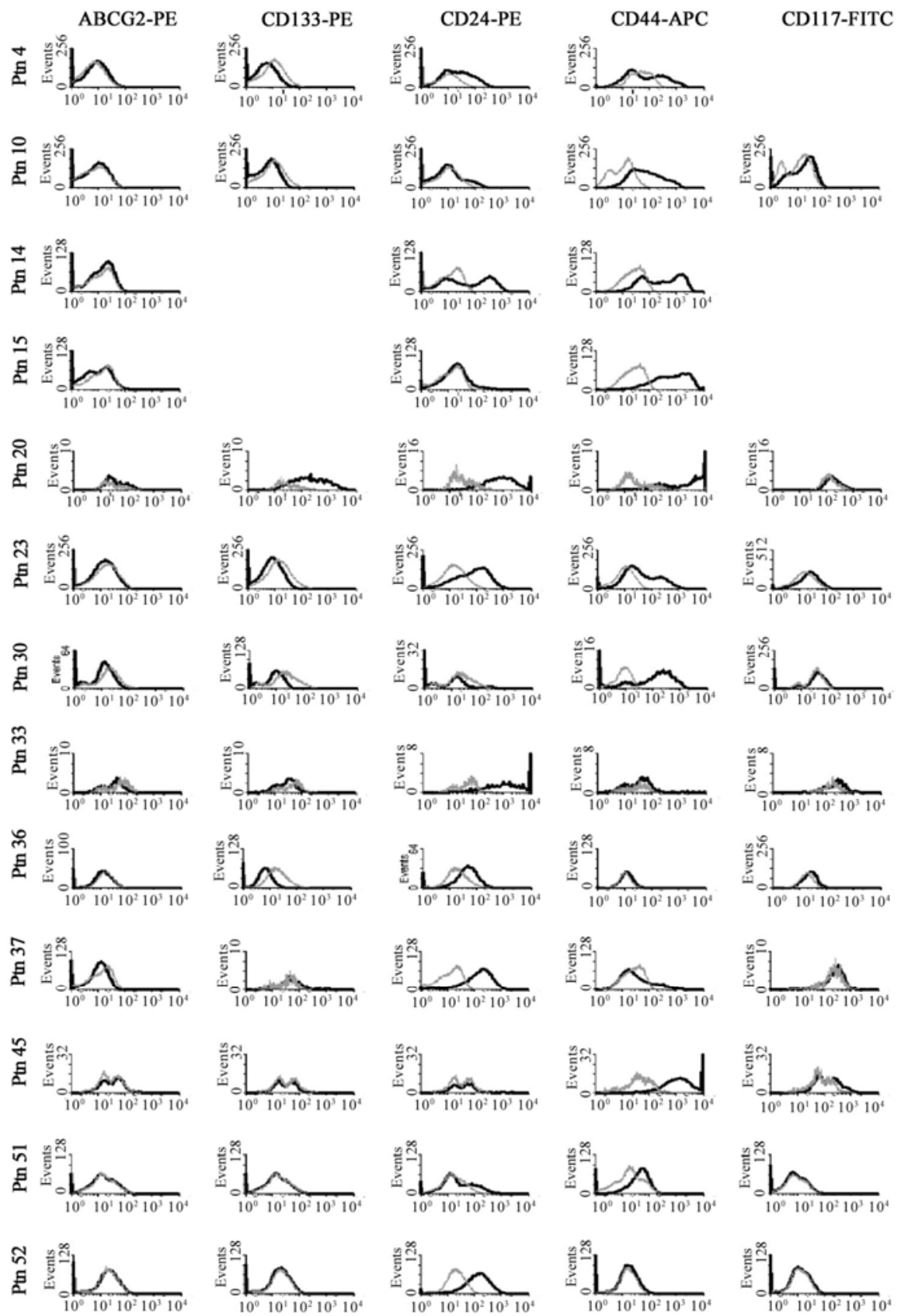

(a)

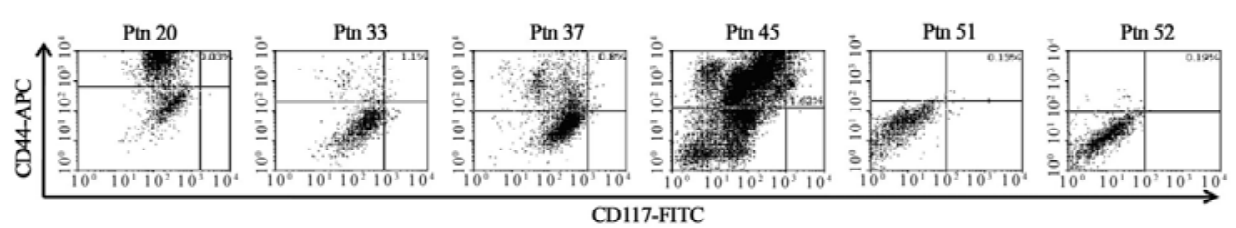

(b)

Figure 1. Expression of putative ovarian CSC markers. A. Isotype controls are indicated by the grey lines. B. Double staining of CD44 and CD117 for several patients tumor cells. 


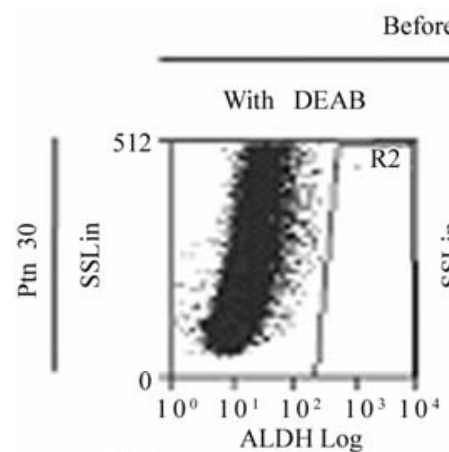

efore culture
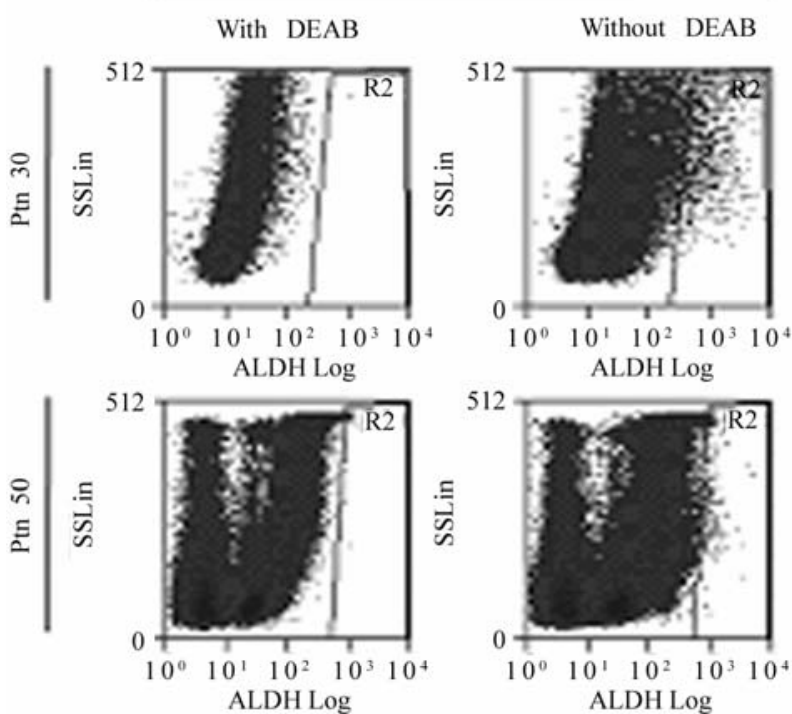
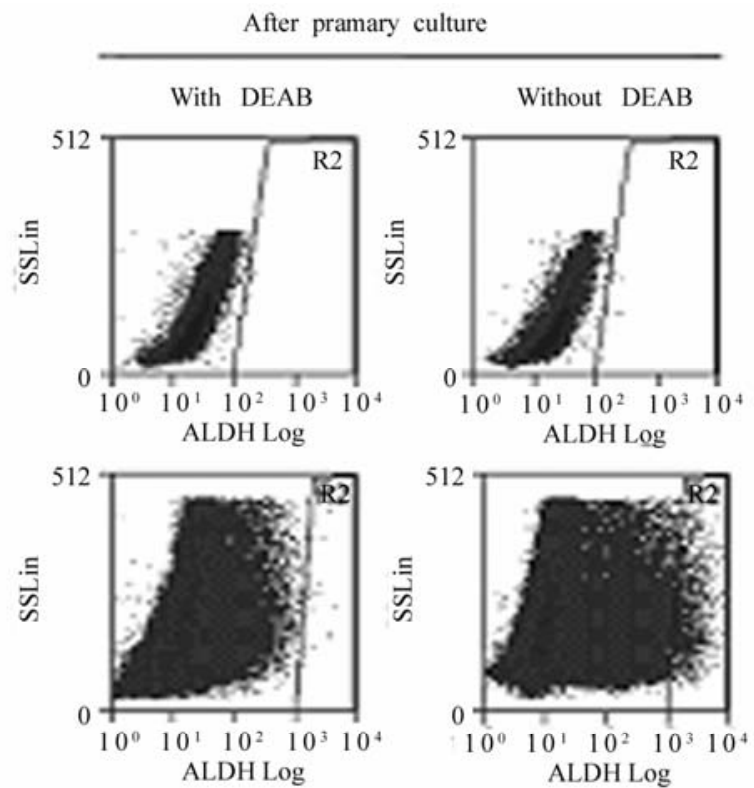

Percentage of gated $\mathrm{ALDH}^{+}$cell in Region 2

\begin{tabular}{ccccc}
\hline & \multicolumn{2}{c}{ Before culture } & \multicolumn{2}{c}{ After pramary culture } \\
\hline $\operatorname{Ptn} 30$ & 0.01 & 2.74 & 0.01 & 0.01 \\
$\operatorname{Ptn} 50$ & 0.03 & 0.18 & 0.03 & 1.29 \\
\hline
\end{tabular}

(a)
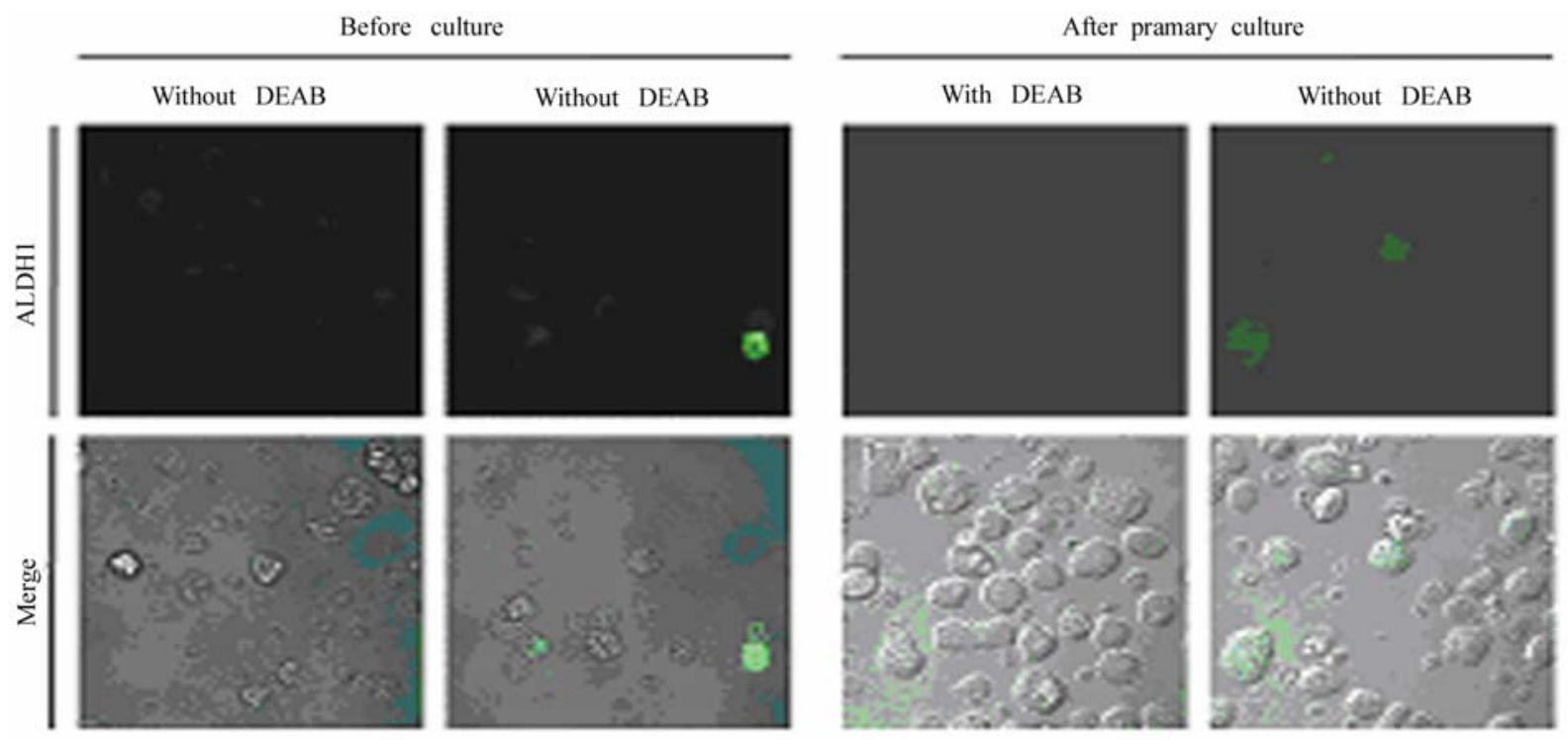

(b)

Figure 2. ALDH-positive cells are reduced during primary culture. A. Representative flow cytometry analysis of ascites-derived ovarian tumor cells using the ALDEFLUOR assay. Cells were incubated with ALDEFLUOR substrate BAAA and the specific inhibitor of ALDH, DEAB, for 45 min. Gates were set according to DEAB control (ALDH ${ }^{+}$cells $\leq 0.03 \%$ ). B. ALDH 1 staining of ascites-derived tumor cells before culture. ALDH 1 positive cells were very bright comparing to DEAB treated cells. ALDH 1 staining of ascites-derived tumor cells after primary culture for 2 weeks. The signal intensity of ALDH 1 positive cells was reduced. 


\subsection{Aldehyde Dehydrogenase 1 (ALDH1) Expression/activity Is Changed in Ovarian Cancer Patient upon Culturing.}

ALDH1 is expressed in stem and progenitor cells of several tissue types, including CSCs. ALDH1 ${ }^{+}$cells are enriched in colon, breast and ovarian cancers. It predicts poor clinical outcome in breast cancer while correlates with poor and favorable prognosis in ovarian cancer $[28,29]$. So we wondered whether ALDH1 can be applied to identify ovarian CSC in cells isolated from ascites. We utilized the ALDEFLUOR assay to assess the presence and expression of the population with ALDH1 enzymatic activity in ascites-derived tumor cells before and after primary culture of 2 weeks. Analysis of freshly isolated as well as frozen tumor cells from different patients showed an average of $2 \%(2.2 \% \pm 2.0, \mathrm{n}=13)$ ALDH1-positive population. However, after 2 weeks of culture the ALDH1-positive cells were reduced to $1 \%$ $(0.5 \% \pm 0.7 \mathrm{n}=15)$ (Figure 2, Table 4). Among the 15 patients tested after primary culture, 14 of them showed significant decrease in ALDH1 expression comparing to fresh cells, while only 1 patient showed up-regulation of ALDH1. Moreover, we also found that ALDH1 signal intensity was reduced upon culturing under confocol microscopy, (Figure 2). From these results we conclude that ALDH1 cannot be used as a functional marker to enrich ovarian CSCs.

\section{Discussion}

The CSC hypothesis has fundamental implications for cancer biology in addition to clinical implications for cancer elimination. The development of novel cancer therapeutics requires targeting this important CSC population, to prevent tumor relapse. The success of these new approaches is based on defining the 'real' CSCs. Several criteria have been established to identify, isolate and characterize CSCs, including self-renewal tumor sphere formation and expression of distinct cell surface antigens, permitting consistent isolation. And based on these criteria, putative ovarian CSCs have been identified and prospectively isolated from patient ascites, ovarian cancer cell lines, primary tumor tissues as well as mouse cell lines. They all proved that only a small subpopulation of tumor cells bearing certain surface makers are capable of self-renewal, and are capable of initiating and supporting the malignant tumor growth. We did a large study with ascites derived from 22 ovarian cancer patients and for the first time revealed that, due to heterogeneity of patients, expression of the putative ovarian CSC makers are not applicable to isolate CSCs from all patients.

Firstly, our study showed that not cells from all pa- tients are capable of anchorage-independent growth and three-dimensional tumor sphere formation in stem cell culture media. This sphere formation difference could be explained by the origin of CSCs in the patients. There are two hypothesis elucidate the origin of CSCs, one claims that CSCs are generated from transformed normal stem cells, so that they can make use of the already active self-renewal machinery. The other claims that CSCs are generated from progenitor cells by regaining the self-renew pathway. We envisage that normal stem cell-derived CSCs are capable of sphere formation, whereas progenitor-derived ones are not. Moreover, it is also possible that the amount of malignant CSCs in some patients was not sufficient to form tumor spheres, and the tumorigenic capacity of the CSCs from each patient is different. However, we cannot exclude that current culture conditions based on other epithelial tumors are not optimal yet for the proliferation of ovarian CSCs from all patients. Interestingly, we found cells from patients of FIGO stage I could form tumor spheres, indicating the existent of CSCs at the initiating stage of malignant tumor growth. Such a concept has important ramifications. It lends support to the hierarchy model of tumor heterogeneity, meaning that only a small subpopulation of malignant cells is responsible for tumor initiation.

Secondly, we demonstrated that those putative makers are also not applicable to isolate CSCs from all primary ovarian tumors, since their expression differs dramatically among patients. For instance, we showed that CD133 was only detected in 2 patients; we found that $\mathrm{CD} 24$ and CD44 were expressed by almost all the patients analyzed, whereas the cell populations bearing CD24 or CD44 in most patients were too large to be considered as malignant stem cells; we also revealed that $\mathrm{CD} 44^{+} \mathrm{CD} 117^{+}$ populations were detectable in only 3 out of 7 patients. Consistently, recent studies using ovarian tumor cell lines as well as primary tumor specimens revealed that putative CSC markers, including ALDH are displayed in a complex pattern [30]. In one study using the NCI60 tumor cell line panel, it is found that expression of CD44, CD24, and CD133 varied greatly even between cell lines of the same tumor type [31]. In the same study, they demonstrated cell populations with ALDH activity ranged widely, from 0 up to $38.8 \%$. In order to increase understanding of how to target and ultimately eradicate an ovarian CSC population, researchers make use of different ovarian tumor materials to isolate those cells from the bulk of cells. However, our results suggest that ovarian cancers are very heterogeneous, study material has a profound influence on the putative markers identified. The complexity of marker expression suggests that therapeutic targeting utilize of different tumor materials could result in different putative CSC populations bear- 
ing distinct surface markers. Future studies aiming to isolate CSCs have to take this into account.

Moreover, we found that expression of putative ovarian CSC markers neither correlate with clonogenic capacity of ascites-derived tumor cells, nor associate with patient histosubtypes. Studies have shown that a small percentage of $\mathrm{CD} 24^{+}$, or $\mathrm{CD} 133^{+}$cells or $\mathrm{CD} 44^{+} \mathrm{CD} 117^{+}$ cells isolated from ovarian tumor specimens or ovarian tumor cell lines were considered ovarian cancer-initiating cell populations. They proved that only a small percentage of isolated cells bearing one of those markers were able to form colonies in vitro, indicating that tumors are composed of biologically and functionally distinct cell populations. And they demonstrated that cells within the tumorigenic clones bear stem cell properties and are capable of transferring the disease into nude mice[19]. However, we found that CD24 was expressed in cells from all tested patients. 2 out of 13 patients were bearing rare populations of $\mathrm{CD} 24^{+}$cells $(<10 \%)$, of which one patient had tumor sphere formation in vitro while the other had not. Whereas 4 out of 13 patients were with extremely large $\mathrm{CD} 24^{+}$populations (> 60\%), of which cells from 2 patients formed in vitro spheres but the others did not. Moreover, in our study CD133 expression was detected in cells from 2 out of 11 analyzed patient ascites, belonging to the serous subtype. One of the 2 patients with large $\mathrm{CD} 133^{+}$population $(73.3 \%$ ) formed tumor sphere while the other patient with $3.7 \% \mathrm{CD} 133^{+}$ cells did not. And in our hands only 3 patients were containing $\mathrm{CD} 44^{+} \mathrm{CD} 117^{+}$cells are restricted to FIGO stage III serous adenocarcinoma, although the patient with lowest $\mathrm{CD} 44^{+} \mathrm{CD} 117^{+}$cell population did not generate tumor spheres. Collectively, these results again indicate that ovarian cancers are very heterogeneous, and even tumors with the same phenotypes might originate from distinct populations of CSCs. These observations indeed indicate that those putative markers cannot be used as a general target to enrich for ovarian CSCs from all histological distinct patients.

In addition to the surface markers, we showed that ABCG2 expression was only detectable in 1 out of 11 analyzed patient ascites, suggesting that $\mathrm{ABCG} 2$ is not necessarily the efflux transporter functional in all the ovarian cancer patients; we cannot exclude the existence and functions of other membrane transporters in chemo-resistance.

Finally, we showed that ALDH1 expression or its activity was changed after primary culture, indicating that it is not a valid marker for ovarian CSC. However, the reason why ALDH1 expression was reduced upon culturing remains unclear. It has been show that ALDH1 is a predictor of favorable prognosis in ovarian cancer by immunohistochemical staining of ALDH1 expression in a large number of primary ovarian carcinomas [29]. In contrast, another study reported that higher ALDH1 expression is significantly associated with poor clinical outcome in serous ovarian cancer.[28] Our study again suggests that different histological type ovarian epithelial tumors have remarkably distinct molecular background. Therefore, the prognostic value of ALDH1 in ovarian cancer still needed to be further investigated.

Here we studied primary cells obtained from ascites of ovarian cancer patients. It remains to be proven that the cells present in the ascites are a reflection of the cells present in the tumor mass. Since stem cells are found in so-called niches and cells in the ascites lost contact with their niche it cannot be excluded that cells in the ascites fluid are not equivalent to the tumor cells in the solid tumor [32]. However, tumor spread in the abdomen of the patients is likely to proceed from ascites cells predicting the presence tumor initiating cells in ascites.

Taken together, our study revealed that ovarian cancer is a heterogonous disease [33] and all the reported putative ovarian CSC markers are not applicable to isolate CSCs from all patients. This distinct marker expression may due to the difference between tumor cell lines and primary tumor materials. Thus, a universal target to isolate ovarian CSCs is required to facilitate tumor elimination, using 'representative' patient materials.

\section{REFERENCES}

[1] R. Gupta, P. Vyas and T. Enver, "Molecular Targeting of Cancer Stem Cells," Cell Stem Cell, Vol. 5, No. 2, 2009, pp. $125-126$.

[2] C. Tang, B. T. Ang and S. Pervaiz, "Cancer Stem Cell: Target for Anti-cancer Therapy, "Journal of the Federation of American Societies for Experimental Biology, Vol. 21, No. 14, 2007, pp. 3777-3785.

[3] M. Al-Hajj, M. W. Becker, M. Wicha, I. Weissman and M. F. Clarke, "Therapeutic Implications of Cancer Stem Cells," Current Opinion in Genetics \& Development, Vol. 14, No. 1, 2004, pp. 43-47.

[4] M. Al-Hajj and M. F. Clarke, "Self-renewal and Solid Tumor Stem Cells," Oncogene, Vol. 23, No. 43, 2004, pp. 7274-7282.

[5] M. Al-Hajj, M. S. Wicha, A. Benito-Hernandez, S. J. Morrison and M. F. Clarke, "Prospective Identification of Tumorigenic Breast Cancer Cells," Proceedings of the National Academy of Sciences of the United States of America Vol. 100, No. 7, 2003, pp. 3983-3988.

[6] G. Dontu, M. Al-Hajj, W. M. Abdallah, M. F. Clarke and M. S. Wicha, "Stem Cells in Normal Breast Development and Breast Cancer," Cell Proliferation, vol. 36 , Suppl.1, 2003, pp. 59-72.

[7] T. Hussenet, D. Dembele, N. Martinet, J. M. Vignaud and S. du Manoir, "An Adult Tissue-specific Stem Cell Molecular Phenotype is Activated in Epithelial Cancer 
Stem Cells and Correlated to Patient Outcome," Cell Proliferation, Vol. 9, No. 2, 2010, pp. 321-327.

[8] Bonnet and J. E. Dick, "Human Acute Myeloid Leukemia is Organized as a Hierarchy that Originates from a Primitive Hematopoietic Cell," Nature Medicine, Vol. 3, No. 7, 1997, pp. 730-737.

[9] N. Barker, R. A. Ridgway, J. H. van Es, M. van de Wetering, H. Begthel, M. van den Born, E. Danenberg, A. R. Clarke, O. J. Sansom and H. Clevers, "Crypt Stem Cells as the Cells-of-origin of Intestinal Cancer," Nature, Vol. 457, No. 5, 2009, pp. 608-611.

[10] M. P. Buzzeo, E. W. Scott and C. R. Cogle, "The Hunt for Cancer-initiating Cells: A History Stemming from Leukemia," Leukemia, Vol. 21, No. 8, 2007, pp. 1619-1627.

[11] A. T. Collins, P. A. Berry, C. Hyde, M. J. Stower and N. J. Maitland, "Prospective Identification of Tumorigenic Prostate Cancer Stem Cells," Cancer Research, Vol. 65, No. 23, 2005, pp. 10946-10951.

[12] P. Dalerba, S. J. Dylla, I. K. Park, R. Liu, X. Wang, R. W. Cho, T. Hoey, A. Gurney, E. H. Huang, D. M. Simeone, A. A. Shelton, G. Parmiani, C. Castelli and M. F. Clarke, "Phenotypic Characterization of Human Colorectal Cancer Stem Cells," Proceedings of the National Academy of Sciences of the USA, Vol. 104, No. 23, 2007, pp. 10158-10163.

[13] D. Fang, T. K. Nguyen, K. Leishear, R. Finko, A. N. Kulp, S. Hotz, P. A. Van Belle, X. Xu, D. E. Elder and M. Herlyn, "A Tumorigenic Subpopulation with Stem Cell Properties in Melanomas," Cancer Research, Vol. 65, No. 20, 2005, pp. 9328-9337.

[14] P. C. Hermann, S. L. Huber, T. Herrler, A. Aicher, J. W. Ellwart, M. Guba, C. J. Bruns and C. Heeschen, "Distinct Populations of Cancer Stem Cells Determine Tumor Growth and Metastatic Activity in Human Pancreatic Cancer," Cell Stem Cell, Vol. 1, No. 3, 2007, pp. 313-323.

[15] S. K. Singh, I. D. Clarke, M. Terasaki, V. E. Bonn, C. Hawkins, J. Squire and P. B. Dirks, "Identification of a Cancer Stem Cell in Human Brain Tumors," Cancer Research, Vol. 63, No. 18, 2003, pp. 5821-5828.

[16] S. Zhang, C. Balch, M. W. Chan, H. C. Lai, D. Matei, J. M. Schilder, P. S. Yan, T. H. Huang, and K. P. Nephew, "Identification and Characterization of Ovarian Cancer-initiating Cells from Primary Human Tumors," Cancer Research, Vol. 68, No. 11, 2008, pp. 4311-4320.

[17] M. D. Curley, V. A. Therrien, C. L. Cummings, P. A. Sergent, C. R. Koulouris, A. M. Friel, D. J. Roberts, M. V. Seiden, D. T. Scadden, B. R. Rueda and R. Foster, "CD133 Expression Defines a Tumor Initiating Cell Population in Primary Human Ovarian Cancer," Stem Cells, Vol. 27, No. 12, 2009, pp. 2875-2883.

[18] G. Ferrandina, E. Martinelli, M. Petrillo, M. G. Prisco, G. Zannoni, S. Sioletic and G. Scambia, "CD133 Antigen Expression in Ovarian Cancer," BioMed Central Cancer, Vol. 9, 2009, pp. 221.

[19] M. Q. Gao, Y. P. Choi, S. Kang, J. H. Youn and N. H.
Cho, "CD24+ Cells from Hierarchically Organized Ovarian Cancer are Enriched in Cancer Stem Cells," Oncogene, Vol. 29, No. 18, 2010, pp. 2672-2680.

[20] L. Hu, C. McArthur and R. B. Jaffe, "Ovarian Cancer Stem-like Side-population Cells are Tumourigenic and Chemoresistant," British Journal Of Cancer, Vol. 102, No. 8, 2010, pp. 1276-1283.

[21] P. P. Szotek, R. Pieretti-Vanmarcke, P. T. Masiakos, D. M. Dinulescu, D. Connolly, R. Foster, D. Dombkowski, F. Preffer, D. T. Maclaughlin and P. K. Donahoe, "Ovarian Cancer Side Population Defines Cells with Stem Cell-like Characteristics and Mullerian Inhibiting Substance responsiveness," Proceedings of the National Academy of Sciences of the USA, Vol. 103, No. 30, 2006, pp. 11154-11159.

[22] L. Patrawala, T. Calhoun, R. Schneider-Broussard, J. Zhou, K. Claypool and D. G. Tang, "Side Population Is Enriched in Tumorigenic, Stem-Like Cancer Cells, whereas ABCG2+ and ABCG2- Cancer Cells are Similarly Tumorigenic," Cancer Research, Vol. 65, No. 14, 2005, pp. 6207-6219.

[23] R. W. Robey, K. K. To, O. Polgar, M. Dohse, P. Fetsch, M. Dean and S. E. Bates, "ABCG2: a Perspective," Advanced Drug Delivery Reviews, Vol. 61, No. 11, 2009, pp. 3-13.

[24] D. Ponti, A. Costa, N. Zaffaroni, G. Pratesi, G. Petrangolini, D. Coradini, S. Pilotti, M. A. Pierotti and M. G. Daidone, "Isolation and in Vitro Propagation of Tumorigenic Breast Cancer Cells with Stem/progenitor Cell Properties," Cancer Research, Vol. 65, No. 13, 2005 , pp. 5506-5511.

[25] S. A. Bapat, A. M. Mali, C. B. Koppikar, and N. K. Kurrey, "Stem and Progenitor-Like Cells Contribute to the Aggressive Behavior of Human Epithelial Ovarian Cancer," Cancer Research, Vol. 65, No.8, 2005, pp. 3025-3029.

[26] T. Liu, W. Cheng, D. Lai, Y. Huang and L. Guo, "Characterization of Primary Ovarian Cancer Cells in Different Culture Systems," Oncology Reports, Vol. 23, No. 5, 2010, pp. 1277-1284.

[27] M. Y. Fong and S. S. Kakar, "The Role of Cancer Stem Cells and the Side Population in Epithelial Ovarian Cancer," Histology and Histopathology, Vol. 25, No. 1, 2010, pp. 113-120.

[28] S. Deng, X. Yang, H. Lassus, S. Liang, S. Kaur, Q. Ye, C. Li, L. P. Wang, K. F. Roby, S. Orsulic, D. C. Connolly, Y. Zhang, K. Montone, R. Butzow, G. Coukos and L. Zhang, "Distinct Expression Levels and Patterns of Stem Cell Marker, Aldehyde Dehydrogenase Isoform 1 (ALDH1), in Human Epithelial Cancers," Public Library of Science ONE, Vol. 5, No. 4, pp. e10277.

[29] B. Chang, G. Liu, F. Xue, D. G. Rosen, L. Xiao, X. Wang and J. Liu, "ALDH1 Expression Correlates with Favorable Prognosis in Ovarian Cancers," Modern Pathology, Vol. 22, No. 6, 2009, pp. 817-823.

[30] S. Y. Park, H. E. Lee, H. Li, M. Shipitsin, R. Gelman and K. Polyak, "Heterogeneity for Stem Cell Related Markers 
According to Tumor Subtype and Histologic Stage in Breast Cancer," Clinical Cancer Research, Vol. 16, No. 3, 2010, pp. 876-887.

[31] C. H. Stuelten, S. D. Mertins, J. I. Busch, M. Gowens, D. A. Scudiero, M. W. Burkett, K. M. Hite, M. Alley, M. Hollingshead, R. H. Shoemaker and J. E. Niederhuber, "Complex Display of Putative Tumor Stem Cell Markers in the NCI60 Tumor Cell Line Panel," Stem Cells, Vol. 28, No. 4, 2010, pp. 649-660.

[32] E. Katz, K. Skorecki and M. Tzukerman,
"Niche-dependent Tumorigenic Capacity of Malignant Ovarian Ascites-derived Cancer Cell Subpopulations," Clinical Cancer Research, Vol. 15, No. 1, 2009, pp. 70-80.

[33] M. Köbel, S. E. Kalloger, N. Boyd, S. McKinney, E. Mehl, C. Palmer, S. Leung, N. J. Bowen, D. N. Ionescu, A. Rajput, L. M. Prentice, D. Miller, J. Santos, K. Swenerton, C. B. Gilks and D. Huntsman, "Ovarian Carcinoma Subtypes are Different Diseases: Implications for Biomarker Studies,"Public Library of Science Medicine, Vol. 5, 2008, pp. e232. 